less practical importance, are not immediately recognisable by those whose imagination has been stunted by the methods employed in their own youth. An inadequate cramping education tends to prolong itself; for youth, with all its hidden powers calling for development, must submit to the methods imposed by age. It is probable that no branch of the human race is more difficult to move than our own. The thought sometimes arises that salvation can only be found, if at all, by national disaster; and then, under modern conditions, the remedy may be too late and recovery impossible. About forty years ago Huxley delivered the powerful and eloquent addresses on education reprinted in "Lay Sermons, Addresses, and Reviews," and yet the same subject is felt to be still the paramount question of the hour when one of our foremost scientific men is invited to deliver the Romanes lecture in 1905. It is disheartening to read Huxley's admirable and convincing essays and to realise how small has been the effect. But a reformer who would achieve anything must not give way to despondency : it is only by hope and confidence in the future that mankind can be moved. And this latest appeal has one great advantage over the old. The history of man could not have been spoken of forty years ago as it can to-day; his interference with nature is also far more evident. In this latest appeal, the imagination of the author aroused by these considerations has originated the splendid argument founded on the deeds, the delay, and yet, in spite of delay, the inevitable triumphant destiny of "man. It is not too much to hope that the power and the onward sweep of this great argument will carry away many an old but not time-honoured barrier, and many an obstacle built up, alas, in modern times, intervening between man and the race that is set before him. E. B. P.

\section{INTERNATIONAL ASSOCIATION OF ACADEMIES.}

A BRIEF note on the third triennial general assembly appeared in NATyRy for May 30. The following academie rere rapented :-Amsterdam, Berlin, Brûssels Bydopest, Christiania, Göttingen, Copenhagen, Leiptig, London (R.Soc.), London (B.Acad, Whadrid, Munich, Paris (Belies-Lettres), Paris (\$cienc\&), Paris (Morales et Politiques), St. Petersburg, Rome, Stockholm, Tokio, Washington, Vienna. The English representatives mentioned in NATURE for May 30 were all present with the exception of Sir Norman Lockyer.

The proceedings opened on the morning of May 29 with a brief address from Prof. Suess, the president. Dr. Böhm-Bawerk (Vienna) was nominated vice-president, and the following as secretaries:German, Gomperz (Vienna), von Lang (Vienna); French, de Lapparent (Paris), Senart (Paris); English, Turner (London), Gollancz (London).

M. Darboux (Paris) then announced that a medal had been struck by the French Government in honour of the first meeting at Paris. He presented the first copy to the Vienna Academy, and said that a copy would be sent to each constituent academy. The assembled representatives of science had been pictured on the medal as young girls, and, though scarcely in accord with the appearances round him at the moment, this representation had at least the merit of suggesting that science was always young.

It was decided by small majorities not to place on the agenda paper either the selection of an auxiliary language or the proposal for a symbolic nomenclature for machinery. Other questions dealt with at this meeting related to statutes and procedure.

No. 1964, VOL. 76]
On Thursday, May 30, the association met in two sections. In the section of science the report of the Brain Commission was received and placed on the minutes, no vote of approval being necessary since this commission has autonomous powers. A committee appointed in Igo4 by the association to "consider the best method of bringing existing organisations into relation with the association " reported that they had made certain suggestions to the International Seismological Association which had been adopted, and that in consequence it had become possible for the United States, Austria, and England to join that association, while the adhesion of France was confidently expected.

Sir George Darwin presented a reporc on the possible cooperation of the International Geodetic Association in geological researches, by means of the study of anomalies in the value of gravity. There were difficulties (especially from lack of funds) in organising such cooperation; but the apparatus of Baron Eötvös seemed likely to give just the information desired, and it was to be hoped that the Hungarian Government would encourage experiments with this apparatus.

Prof. von Than announced that the Hungarian Government had promised a sum of 60,000 kronen annually for three years for work with the apparatus of Baron Eötvös. This announcement was naturally received with acclamation, and it was resolved to tender cordial thanks to the Hungarian Government. It was also decided to represent to the Italian Government the great importance of similar researches in the neighbourhood of active volcanoes such as Vesuvius.

A report by M. Ch. Lallemand on levelling operaions urged the desirability of repeating precise levellings two or three times per century in all countries, in order to determine possible changes.

As bearing on the general importance of the work of the Geodetic Association, M. Darboux referred to the work of Prof. Milne in directing attention to the possible connection between variation of latitude and seismic phenomena.

With regard to the survey of the zoth meridian of longitude, Sir G. Darwin was able to report, on the authority of Sir David Gill, that the survey was now approaching the northern limits of British territory, where it was hoped that it would be taken over by Germany and carried through German territory. Further, that there was a good prospect that certain R.E. officers would be able to survey $2^{\circ}$ of the meridian, in the neighbourhood of the Equator, and that Captain Lyons, F.R.S., the director of the Egyptian Survey, was hoping to begin the triangulation of the Nile Valley in the coming winter.

An interesting report of the Marey Institute was received, including the announcement of munificent assistance from the French Government and the city of Paris. Here again the Association hastened to tender cordial thanks for generous Government aid to science.

The proposal of the Royal Societr for a committee on lunar nomenclature was adopted without opposition; and the following were nominated to serve on the committee, with power to add to their number:Lœewy (chairman), Newcomb, Weiss, Franz, Saunder, and Turner.

The International Union for Solar Research successfully solicited the patronage of the association, in token whereof they were to report to it every three years, and to reserve one place on the executive committee (of three members) for a member to be nominated by the leading academy for the time being. It was unanimously decided, on the motion of Prof. Hale (Washington), respectfully to invite the Austrian 
Government to consider whether, in view of the number of favourable stations existing in the neighbourhood of Vienna, they could encourage and assist solar observations.

An important resolution concerning the organisation of meteorological stations was moved by Dr. W. N. Shaw (London), and unanimously carried, as follows :-

Consideration of the distribution of meteorological stations over the globe shows that stations in the far north and on islands in the various oceans are of special importance; the International Association of Academies desires therefore to express the hope that the Governments concerned will take any necessary steps for securing the continuance of observations where they already exist; for the modification of their form, if necessary, to bring them into conformity with meteorological usage; for establishing stations where they do not yet exist; and for placing the observations at the service of science by suitable publication. As regards the far north, observations are desired from two or three stations, at least, in the north of Siberia and of the Continent of America respectively, and as regards the islands, the following list is suggested:Greenland, Færöe lslands, Azores, Madeira, Canaries, Cape Verde, Ascension, St. Helena, Falklands, Fernando Naronha, Staten Island, Fernando Po, West Indies, Bermudas, Sandwich Islands, Carolines, Guam, Bismarck Archipelago, Samoa, Fiji, New Caledonia, Tahiti, Java, Borneo, Seychelles, Maurice, Réunion, Madagascar, Zanzibar, Socotra, Chagos Archipelago, Christmas Island, Karmaluki.

The Association reassembled in the afternoon, for a sitting which it was ultimately found necessary to adjourn until Sunday morning, June 2. The report on the publication of the works of Leibniz was received; already a catalogue of the Leibniz MSS. had been prepared and printed. The Association expressed the hope that the three academies which had prepared this catalogue (the Paris Academies of Science and of Moral and Political Science, and the Berlin Academy) would proceed to undertake and carry through a scientifically complete edition of the works of Leibniz, and that the necessary Government aid would be forthcoming.

The proceedings of the two sections were then approved in detail by the general assembly, including reports from the letters section on the interriational loan of MSS., on the Greek Thesaurus, and on the Corpus Medicorum Antiquorum.

It was decided to accept the invitation to hold the next meeting in Rome (1910), probably at Easter.

There were, of course, many hospitable entertainments. The Vienna Academy invited the delegates to the annual meeting on Mav 28 ; the president entertained them at dinner on May 29 ; there were delightful expeditions to the Semmering on June $\mathrm{I}$, and to the Schloss Kreuzenstein on June 2, which the Graf von Wilczek (the organiser of the Polar expedition which discovered Franz Josef land) has rebuilt on the old model, and filled with all the beautiful old pictures and pieces of furniture which can be collected. Finally, the delegates had the honour of being received by the Emperor in person on the evening of June 2, and of being present at the Opera on his invitation.

The success of the whole meeting was attested by the cordial words spoken at its conclusion by MM. Darboux (Paris), Schuster (London), and Kikuchi (Tokio), who joined in congratulating Prof. Suess and the Vienna Academy on the able manner in which the duties of the "leading academy" had been discharged during the last three years.

NO. I964, vOL. 76]

H. H. Tukner.

\section{THE LEICESTER MEETING OF THE BRITISH ASSOCIATION.}

I EICESTER people evidently intend doing their 1 utmost to make the pirst visit of the British Association to thon to as successful as it will be welcome, and the raceting itself promises to be both largely and influentially attended. Many foreign visitors with be entertained as guests by the local committee, the list already including representatives of science Prom the Cape, Canada, the United States, France, Germany, Austria, Russia, Switzerland, Holland, Prussia, Italy, Norway, Denmark, Sweden, and Greece.

The opening meeting is to be held in the Royal Opera House on Wednesday, July 3I, at 8.30 p.m., when Prof. Ray Lankester, the retiring president, will vacate the chair, and Sir David Gill, K.C.B., F.R.S., assume the presidency and deliver his inaugural address. On Friday, August 2, a discourse on "The Arc and Spark in Radio-telegraphy" is to be delivered by $\mathrm{Mr}$. W. Duddell in the same building, and on Monday, August 5, Dr. F. A. Dixey will discourse on "Recent Developments in the Theory of Mimicry" in the 'Temperance Hall. A lecture to the operative classes will be given on Saturday, August 3, also in the Temperance Hall, by Prof. H. A. Miers, F.R.S., on "The Growth of a Crystal."

Excursions are being arranged to Belvoir Castle, the seat of the Duke of Rutland; Chatsworth, the Duke of Devonshire's Midland home; Haddon Hall, and to Peterborough Cathedral, with an invitation to tea in the Palace grounds from the Bishop. In addition to a general excursion to the Charnwood Forest, there will be a special one both there and to the district of Belvoir for geologists, whilst the botanical section is also planning walks in the same district.

An interesting trip will be that over the Leicester and Swannington railway now forming part of the Midland Railway system. This is one of the earliest railways in the kingdom, and the honoured names of George and Robert Stephenson are closely associated with it. Opened for traffic in 1832 , the first object of this railway was the provision of a cheap supply of coal from the district it tapped to Leicester, and there is no doubt its formation greatly influenced the prosperity of the town. From the West Bridge Station, Leicester, the line enters the Glenfield Tunnel, which is 1796 yards long, cut straight and level, I4ft. high, r $2 \mathrm{ft}$. Gin. wide, and built of isin. brickwork. On the opening day a special train conveying the directors left Leicester for Bagworth. In entering the tunnel referred to the chimney of the engine, The Comet, was knocked down, with the result that the passengers travelled to the Glenfield end through thick smoke and dust. The train was stopped at the Glenfield Brook to permit of a general washing of faces and hands. At Bagworth an incline of $\mathrm{x}$ in 29 was originally worked by a rope rooo yards long, 5 inches circumference, the full wagons of coal pulling up the empties. The Swannington incline, $I$ in 17 , has since $I S .3$, been worked by a fixed winding engine and rope. The original engine, one of the first to be fitted with a piston-valve, is still in use. From the commencement, three passenger trains ran daily from the West Bridge Station, Leicester, and these still continue to be run, to almost the original times. It was owing to a collision at this station between an engine and a country cart, and the consequent smashing of a lot of eggs, that the engine whistle was invented for the purpose of sounding warnings. The chief boot and shoe and hosiery works in the town are to be visited, as well as the works of the water and gas and electric lighting undertakings 